\title{
Physico-chemical characterization of Oak, Pine and Sal forest soil profiles of Betalghat Region of Kumaun Himalaya
}

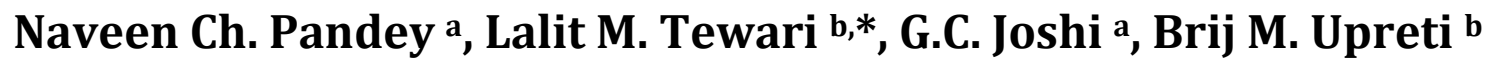

a Regional Ayurvedic Research Institute, (RARI) CCRAS, Thapla, Ranikhet, 263663, Uttarakhand, India b Department of Botany, D.S.B. Campus, Kumaun University, Nainital, India

\section{Article Info}

Received : 20.12.2017

Accepted : 09.06.2018

\begin{abstract}
Soil is one of the basic natural resources on which all forms of terrestrial life co-exist. The soils of three forest types i.e., banj-oak (Quercus leucotrichophora A. Camus) chir-pine (Pinus roxburghii Sargent) and sal (Shorea robusta Gaertn. f.) of Betalghat block, Nainital District, (Kumaun Himalaya). Soils were drawn from three depths viz. $0-10 \mathrm{~cm}, 11-20 \mathrm{~cm}$, 21-30 $\mathrm{cm}$. The present study were studied resulted to soil physico-chemical properties i.e. maximum soil texture (sand $34.30 \%$, silt $57.21 \%$ and clay $33.23 \%$ ), soil moisture (12.6

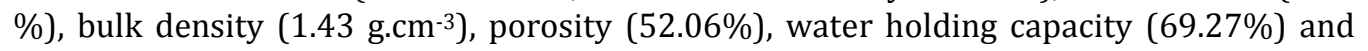
the maximum values of chemical analysis i.e. $\mathrm{pH}$ (6.80), total carbon (3.82\%), organic matter (6.57\%), total nitrogen (0.36\%), available potassium $(267 \mathrm{mg} / \mathrm{kg})$ and available phosphorous $(62 \mathrm{mg} / \mathrm{kg}$ ). Banj-oak forest shows rich physical properties followed by sal and chir-pine forest while chir-pine forest shows rich chemical properties in compared to sal and banj-oak forest.
\end{abstract}

Keywords: Soil physico-chemical characterization, Betalghat region, banj-oak, chir-pine, sal forest, Kumaun Himalaya.

(C) 2018 Federation of Eurasian Soil Science Societies. All rights reserved

\section{Introduction}

Physico-chemical characteristics of forest soils vary in space and time because variation in climate, topography, weathering processes, vegetation cover and several other biotic and abiotic factors (Paudel and Sah, 2003; Sheikh and Kumar, 2010). Forest soil influenced the composition of forest stand and ground cover, rate of tree growth (Bhatnagar, 1965). The vegetation influences the physico-chemical properties of the soil to a great extent. It improves the soil structure, infiltration rate and Water Holding Capacity and aeration (Ilorkar and Totey, 2001; Kumar et al., 2004; Champan and Reiss, 1992). The nutrient thus, returned in the soil, exerts a strong feedback on the ecosystem processes (Pastor et al., 1984). Plants are the main source of soil organic matter, which influences the physico-chemical characteristics of soil such as, texture, $\mathrm{pH}$, water holding capacity and nutrients availability (Johnston, 1986). The nature of soil profile, $\mathrm{pH}$ and nutrient cycling between the soils and plants are the important dimensions to determine the forest site quality. The forests of central Himalayan region have vast variations in the topography, climate and soil conditions, which form a complex ecosystem. Since, the vegetation zones in this region clearly reflect climatic and edaphic variations (Bhatt and Purohit, 2009; Bhatt, 1981) and at the same time the knowledge of physical and chemical properties of soils and climatic conditions of different forest types of temperate region of central Himalaya is meagre.

In the Western Himalayan region (Uttarakhand, India), Oak (Quercus leucotrichophora A. Camus) and Pine (Pinus roxburghii Sargent) are the two major forest types spread over a large part of the forested landscape. Oak is a deep-rooted and moderate-sized evergreen tree that occurs in the moist and cool aspects in the

\footnotetext{
${ }^{*}$ Corresponding author.

Department of Botany, D.S.B. Campus, Kumaun University, Nainital, India

Tel.: +919412362085 e-ISSN: 2147-4249
}

E-mail address: 1_tewari@rediffmail.com 
lower Western Himalayan temperate forest between altitudes 1000 to 2300 m asl (Singh and Singh, 1987; Joshi and Negi, 2015). Pine is a shallow-rooted and large evergreen conifer and a principal species of the Himalayan subtropical forests, which occurs between 800 to $1700 \mathrm{~m}$ asl (Champion and Seth, 1968).

Sal (Shorea robusta Gaertn. f.) belonging to the family Dipterocarpaceae is one of the most important timber trees in India (Deka et al., 2012; Sapkota et al., 2009). Sal forest is widely distributed in tropical India and covers approx. 13.30 per cent of the total forest area of the country (Satya and Nayaka 2005). As per Champion and Seth (1968) it is one of the dominant tree species in the tropical moist as well as dry deciduous forests in India. Some previous studies about physico-chemical characterization of soil were also done by researchers in various forests of Kumaun and Garhwal Himalaya (Joshi and Negi, 2015; Khera et al., 2001; Singh et al., 2009; Semwal et al., 2009; Sharma et al., 2010; Jina et al., 2011; Gairola et al., 2012; Kumar et al., 2013; Joshi, et al., 2013; Mehta et al., 2014; Upreti et al., 2016; Tewari et al., 2016; Bharti, et al., 2016). Present study is focused on the comparison of soil physico-chemical profiling of three different forest types (Oak, Pine and Sal) of Betalghat region of Kumaun Himalaya, Uttarakhand.

\section{Material and Methods}

\section{Study area}

The Present study was carried during the year 2017 in Betalghat region of Nainital district lies between 29038'925” N and 79049'465" E, covering an area of $256.33 \mathrm{Km}^{2}$ with an altitudinal range from 700 to 1800 $\mathrm{m}$ asl. The region is bounded by Tarikhet and Bhikyasain block of Almora district on the north, Kotabag block of Nainital district on the south, Sult block of Almora district on west and Ramgarh block of Nainital district on the east. The vegetation of the region mainly comprises of tropical, sub-tropical and temperate forest.

\section{Collection of soil samples}

Soil samples were collected from three dominated forest types i.e. banj-oak, chir-pine and sal forest of Betalghat region, Nainital District of Kuamun Himalaya.Samples were collected from three different depths with core viz., (i) upper $(0-10 \mathrm{~cm})$, (ii) middle $(11-20 \mathrm{~cm})$ and (iii) Lower $(21-30 \mathrm{~cm})$ for assessing the physico-chemical profiling of the soil. Soil sample was packed in a separate labelled plastic zipper bags and transported to the laboratory for further analysis. The soil samples were oven dried at $45^{\circ} \mathrm{C}$ for $24 \mathrm{~h}$ to reduce the moisture. The detailed description of studied sites was given in Table1. Analytical procedure for soil physico-chemical characterization was done by various methods viz., soil texture (sieve method) (Piper, 1966), soil moisture (Jackson, 1958), water holding capacity (Piper, 1950), soil bulk density ( $\mathrm{gcm}^{-3}$ ) (Black, 1965), soil porosity (Gupta and Dhakshinamoorthy, 1980), pH (Jackson, 1958), soil organic carbon by wet digestion method (Walkley and Black, 1934), total nitrogen by Kjeldahl digestion method (Kjeldahl, 1883), available phosphorus by $0.5 \mathrm{M} \mathrm{NaHCO}_{3}$ (pH 8.5) extraction method (Olsen and Sommers, 1982), available potassium by $1 \mathrm{~N}$ NH4OAc (pH 7.0) extraction method (Black, 1965). Soil chemical properties were performed by soil testing laboratory (Uttarakhand Tea Development Board, Almora) situated at Bhowali, Uttarakhand.

Table 1.Detail description about study sites

\begin{tabular}{lcccc}
\hline Site & Forest Types & Altitude (m asl) & Latitude & Longitude \\
\hline KP & Banj-oak & 1800 & $29^{\circ} 29^{\prime} 366^{\prime \prime} \mathrm{N}$ & $7^{\circ} 24^{\prime} 240^{\prime \prime} \mathrm{E}$ \\
HG & Chir-pine & 1400 & $29^{\circ} 28^{\prime} 151^{\prime \prime} \mathrm{N}$ & $79^{\circ} 27^{\prime} 444^{\prime \prime} \mathrm{E}$ \\
SM & Sal & 700 & $29^{\circ} 32^{\prime} 870^{\prime \prime} \mathrm{N}$ & $7^{\circ} 15^{\prime} 912^{\prime \prime} \mathrm{E}$ \\
\hline
\end{tabular}

\section{Statistical analysis}

The data were analyzed by Analysis of Variance (ANOVA) and the means were compared by Duncan tests at a level of significance of $p<0.05$ using SPSS 22.0 statistical software, to see the level of correlation between different soil parameter, Pearson's correlation matrix was performed while for Cluster analysis, Ward's method was applied.

\section{Results and Discussion}

\section{Soil physical characterization}

Soil is an essential component of our ecosystem, as it serves as an anchorage and source of nutrients for plants. Thus it is the seat, the medium and fundamental raw material for plant growth and maintenance of forest ecosystem by different ecological processes. Among the three forest types percentage of sand ranged from 20.17 to 34.30 whereas silt ranged from 40.37 to 57.21 and percentage of clay ranged from 22.25 to 33.23. Soil moisture content ranged from 4.60 to 12.6. Bulk density ranged from 1.25 to 1.43 . The percentile 
of porosity ranged from 45.15 to 52.06 and maximum percentage of water holding capacity ranged from 33.90 to 69.27 (Table 2).

\section{Soil chemical characterization}

Among the three forest type $\mathrm{pH}$ ranged from 5.57 to 6.80. Total organic carbon ranged from 1.72 to 3.82 . Organic matter ranged from 2.96 to 6.57 . Total nitrogen content ranged from 0.15 to 0.36 . Potassium ranged from 93 to 267 whereas phosphorus ranged from 25 to 62 (Table 3). Nitrogen, phosphorous and potassium are referred to as the primary macronutrients of soil and most important to provide the vitality and performance of plant grown. A comparative analysis of soil physico-chemical properties of oak, pine and sal forest in different parts of the region studied by various workers is given in Table 4.

\section{Correlation among soil physico-chemical properties}

In Banj-oak forest on the basis of correlation matrix sand, carbon and phosphorous showed maximum positive correlation with four physico-chemical properties. Sand with potassium, carbon, organic matter and phosphorus. Carbon with phosphorus, sand, potassium and organic material. Phosphorus with sand, potassium, carbon and organic material while water holding capacity show maximum negative correlation with sand, potassium, carbon, organic material and phosphorus while in Chir-pine forest carbon showed maximum positive correlation five physico-chemical properties viz. sand, clay, potassium, organic matter, nitrogen while water holding capacity showed maximum negative correlation with four physico-chemical properties viz. sand, potassium, carbon and organic material and in Sal forest silt, c:n ratio, potassium, carbon and nitrogen showed maximum correlation with all physico-chemical properties. Silt with c:n ratio, potassium, carbon, organic matter and nitrogen. c:n ratio with silt, potassium, carbon, organic material, and nitrogen. Potassium with silt, c:n ratio, carbon, organic material and nitrogen. Carbon with organic material, nitrogen, silt, c:n ratio and potassium. Nitrogen with silt, c:n ratio, potassium, carbon, and organic material while clay showing maximum negative correlation with silt, c:n ratio, potassium, carbon, organic material and nitrogen (Table 5, 6, 7).

\section{Cluster analysis for physical properties}

Cluster analysis of sand showed three clusters, cluster I (four sites), cluster II (three sites) and cluster III (two sites). While silt showed four clusters, cluster I (three sites), cluster II (three sites), cluster III (two sites) and cluster IV (one site), clay showed four clusters, cluster I (four sites), cluster II (two sites), cluster III (one site) and cluster IV (two site), moisture content showed four clusters, cluster I (three sites), cluster II (three sites), cluster III (two site) and cluster IV (one site), bulk density showed three clusters, cluster I (three sites), cluster II (three sites) and cluster III (three site), porosity showed three clusters, cluster I (three sites), cluster II (three sites) and cluster III (three site) and water holding capacity showed five clusters, cluster I (three sites), cluster II (Two sites), cluster III (One site), cluster IV (Two site) and cluster V (one site) (Figure 1).

\section{Cluster analysis for chemical properties}

Cluster analysis of pH showed five clusters, cluster I (three sites), cluster II (Two sites), cluster III (One site), cluster IV (Two site) and cluster V (one site). While carbon showed four clusters, cluster I (three sites), cluster II (Two sites), cluster III (One site) and cluster IV (three site), organic matter showed four clusters, cluster I (three sites), cluster II (Two sites), cluster III (One site) and cluster IV (three site), nitrogen content showed four clusters, cluster I (three sites), cluster II (two sites), cluster III (three site) and cluster IV (one site), c:n ratio showed four clusters, cluster I (four sites), cluster II (one sites), cluster III (two site) and cluster IV (Two site), potassium showed four clusters, cluster I (two sites), cluster II (three sites), cluster III (two site) and cluster IV (Two site) and phosphorus showed three clusters, cluster I (five sites), cluster II (Two sites) and cluster III (two site) (Figure 2).

\section{Factor analysis for soil physico-chemical properties}

In banj-oak forest factor analysis showed that sand, bulk density, porosity, potassium, carbon, organic matter, phosphorus and nitrogen were positively correlated in comparison to other physico-chemical properties (Figure 4a). Similarly in chir-pine forest nitrogen, porosity, sand, clay and carbon were positively correlated in comparison to other physico-chemical properties (Figure 5a). In sal forest factor analysis showed that potassium, silt, moisture content, c:n ratio, carbon, organic matter and nitrogen were positively correlated in comparison to other physico-chemical properties (Figure 6a). On the basis of observation plots upper depths $(0-10 \mathrm{~cm})$ of all the forest (KP1: banj-oak, HG1: chir-pine, SM1: Sal) showed close correlation with soil physico-chemical properties (Figure 4,5,6b). 

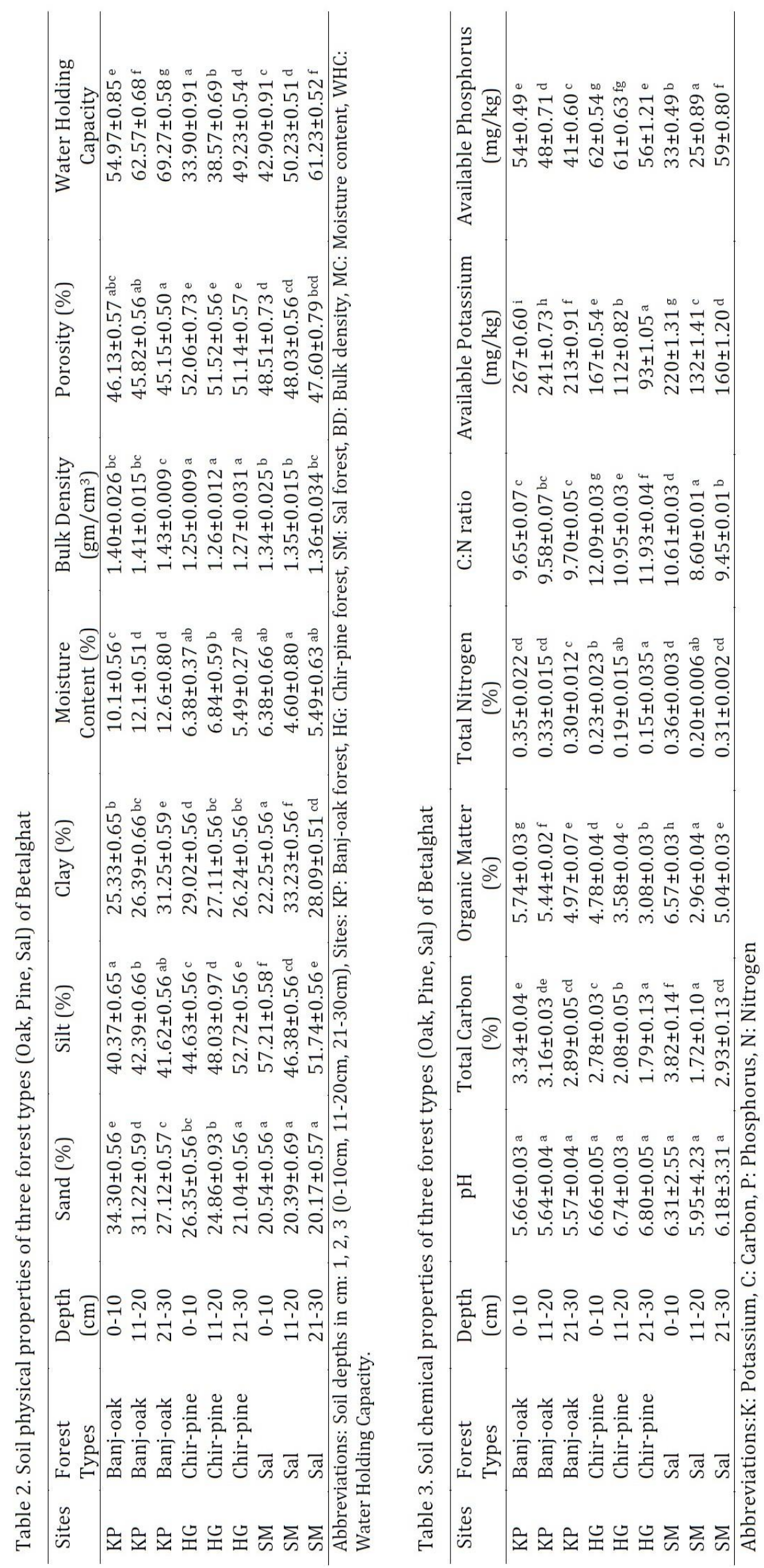


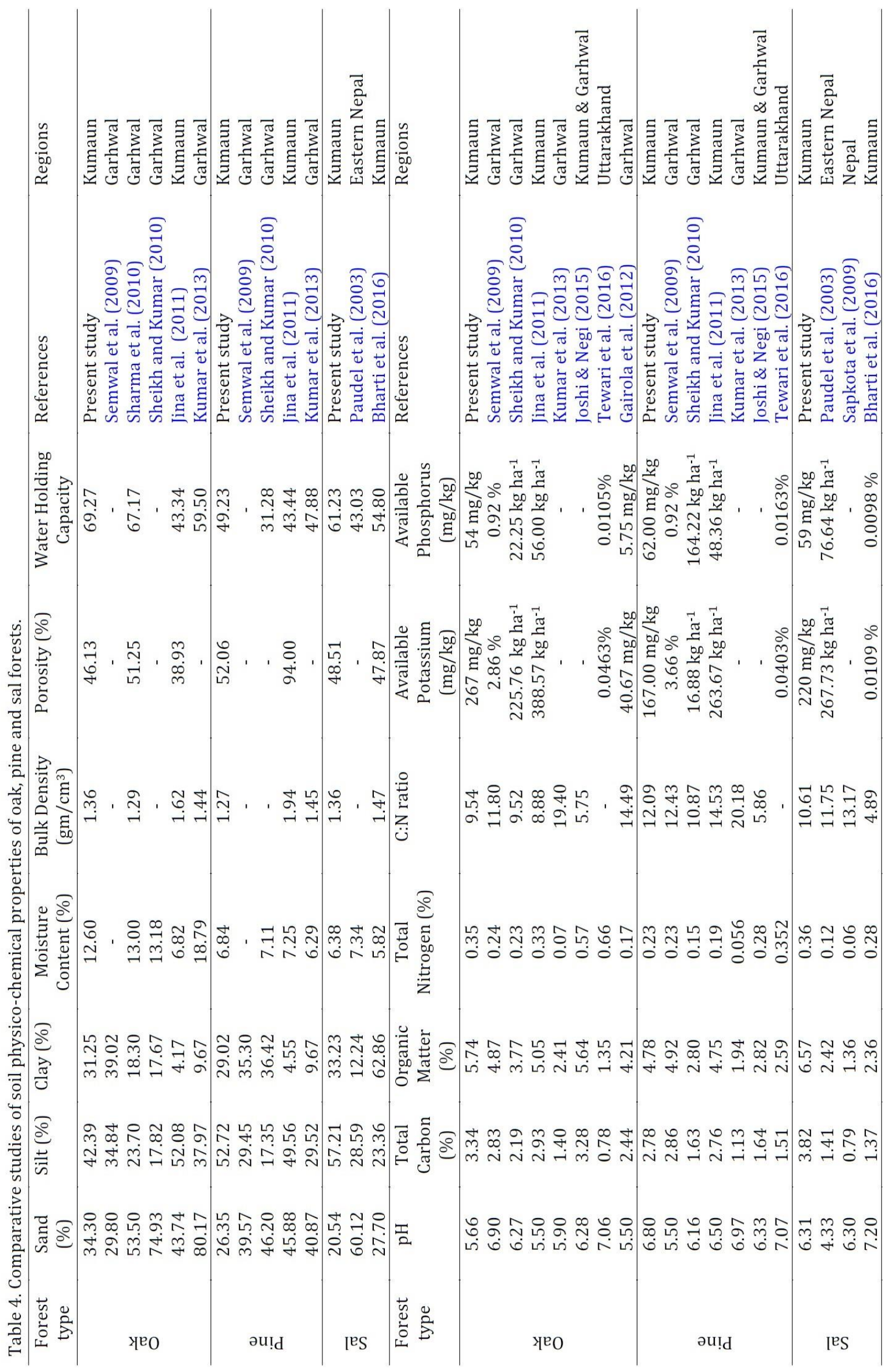




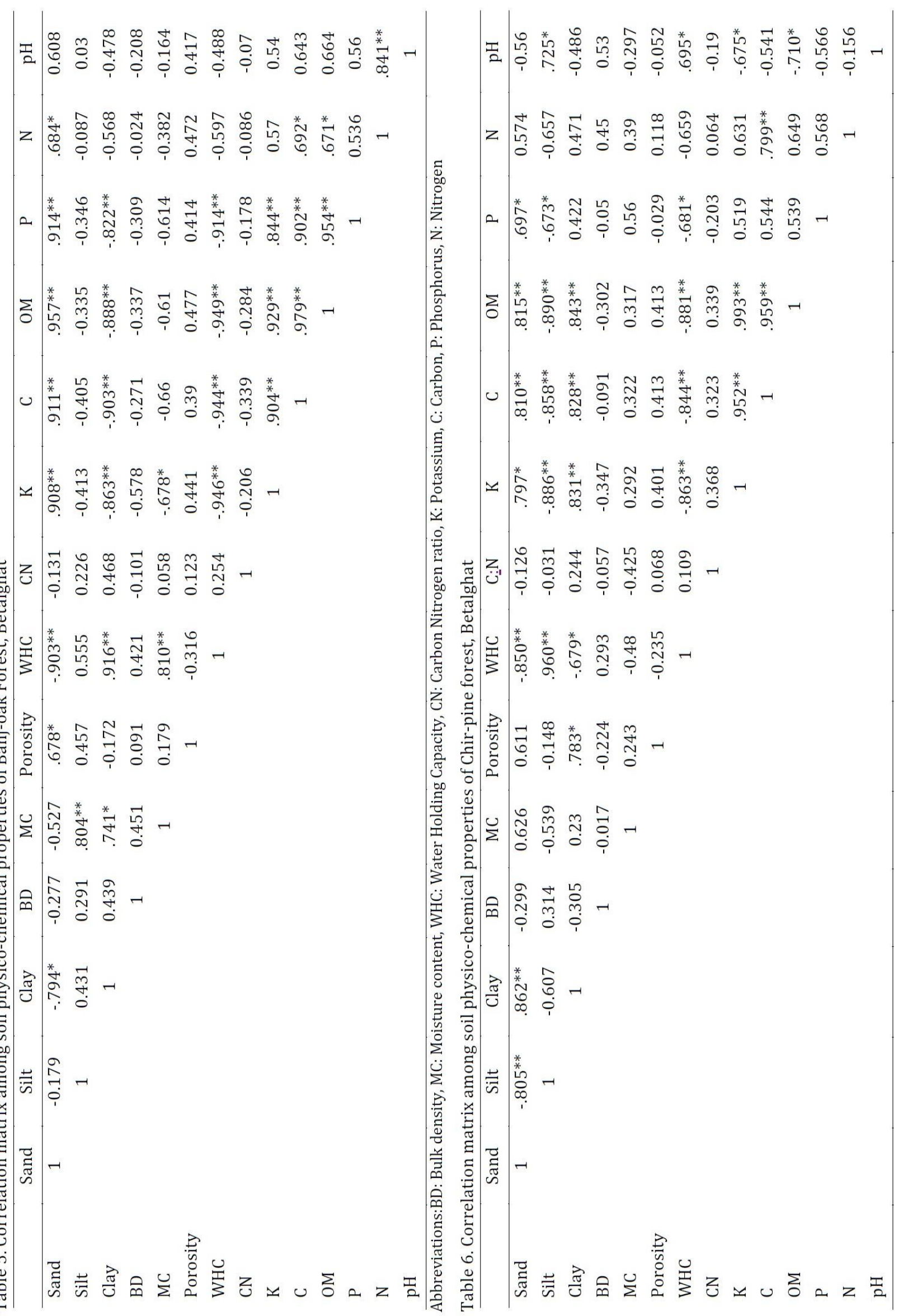




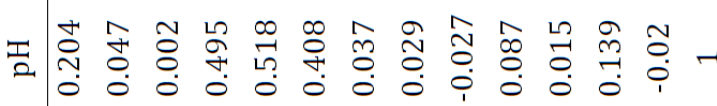

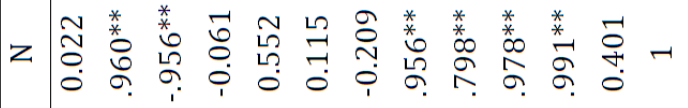

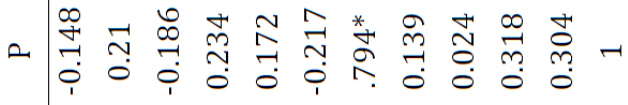

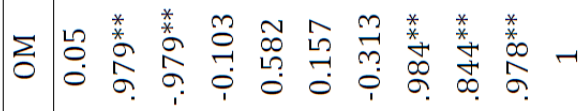

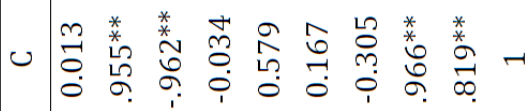

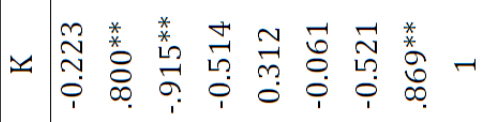

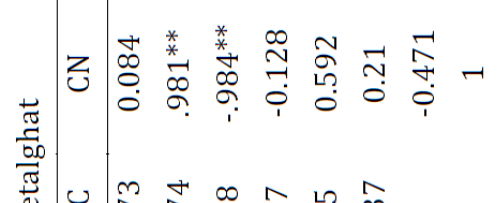

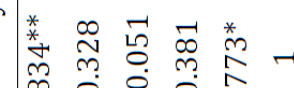

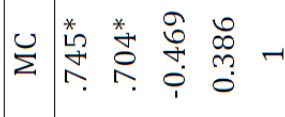

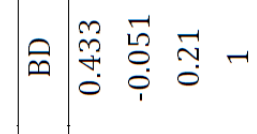

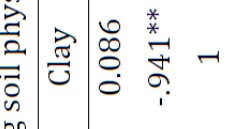

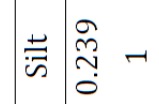




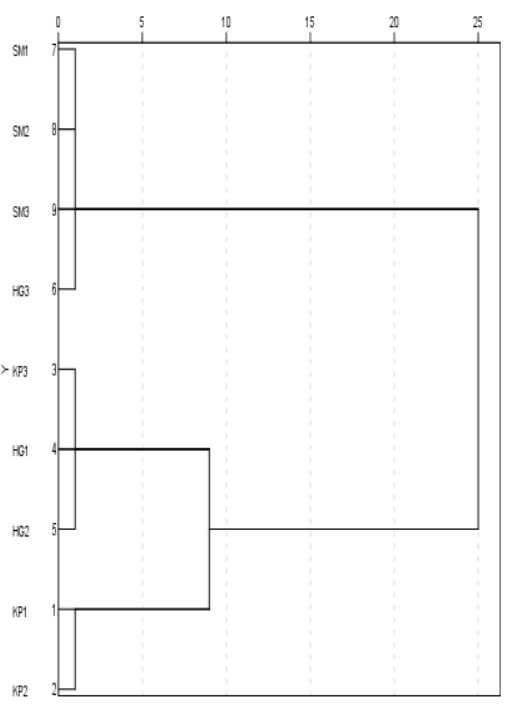

Sand

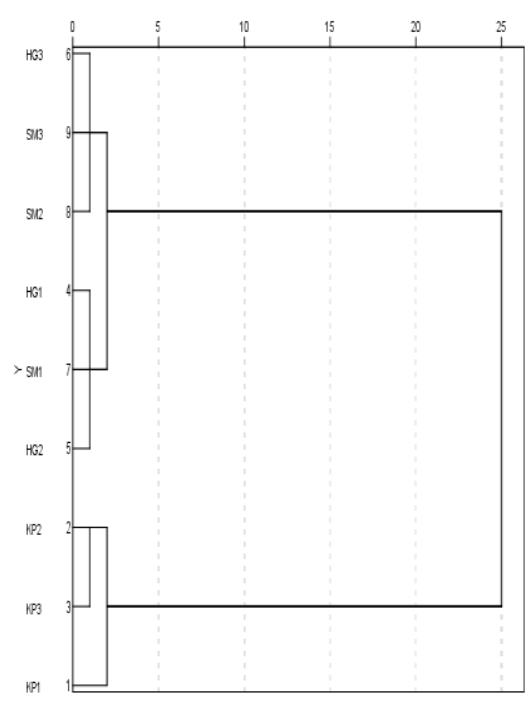

Moisture Content

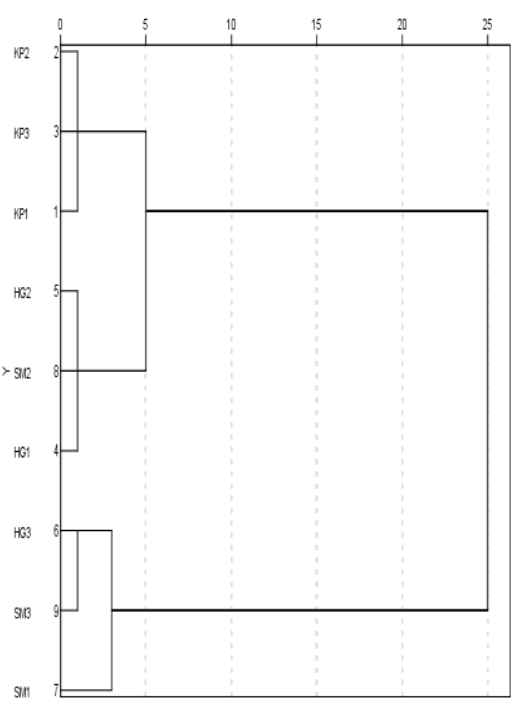

Silt

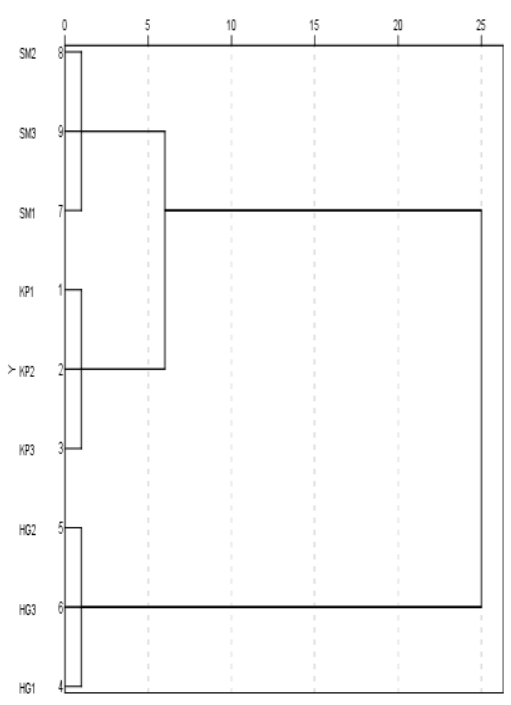

Bulk Density

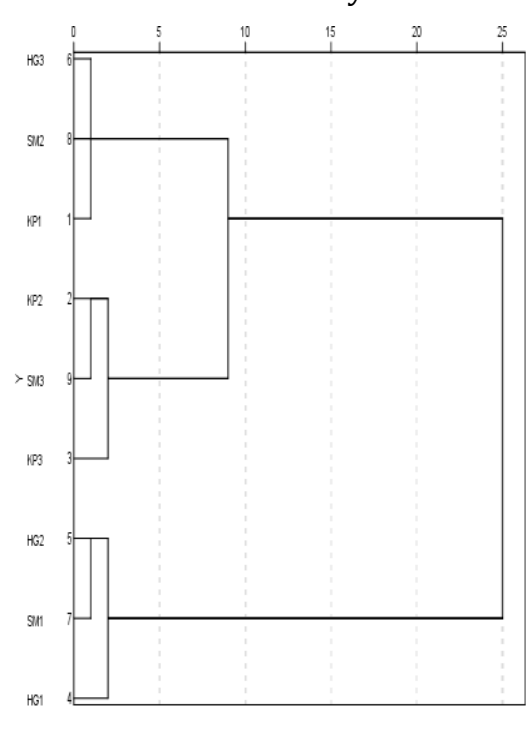

Water Holding Capacity
Clay

Porosity
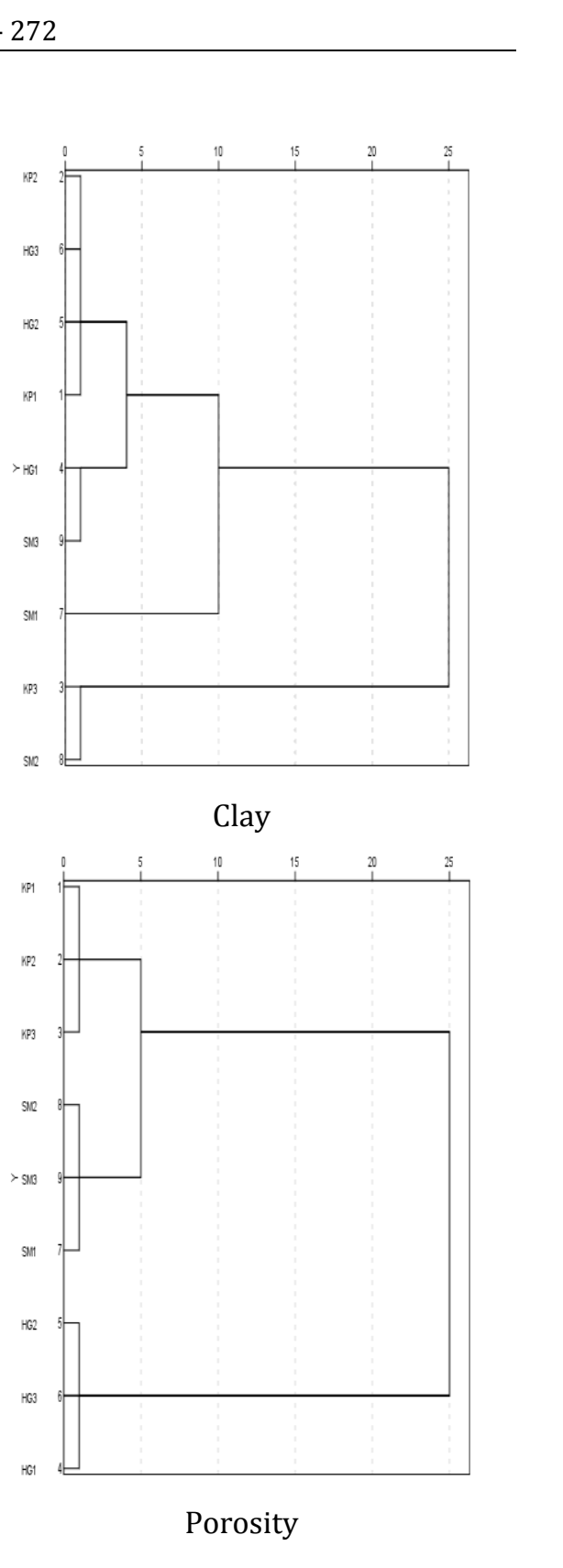


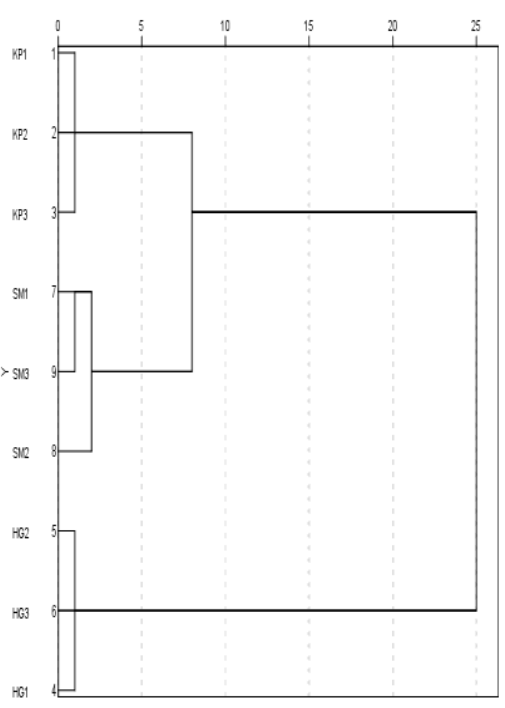

$\mathrm{pH}$

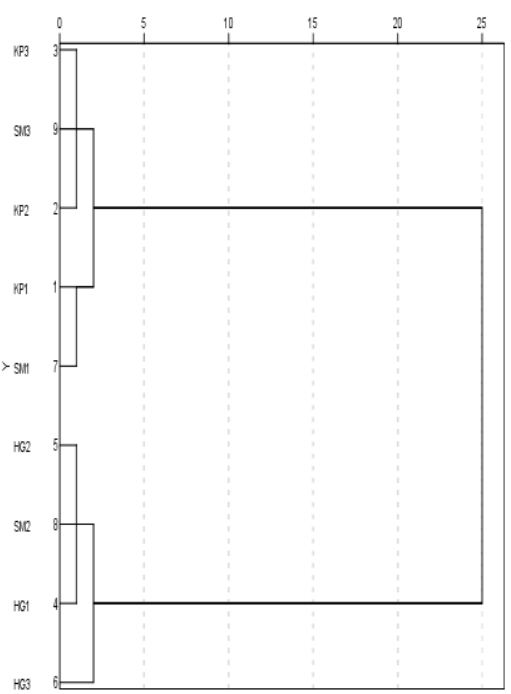

Nitrogen

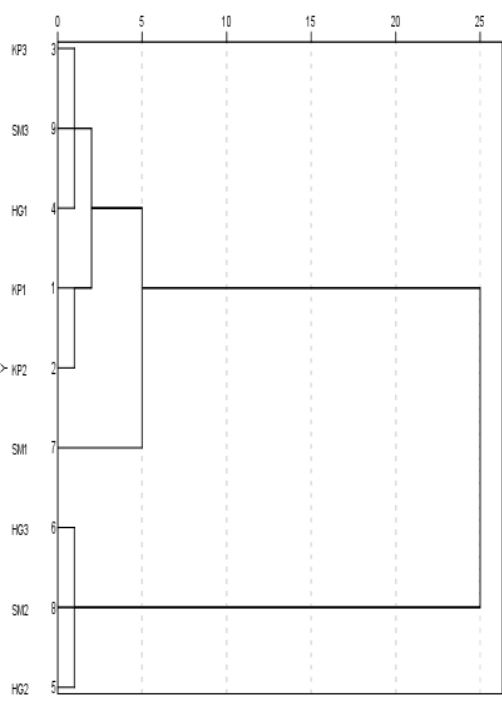

Carbon

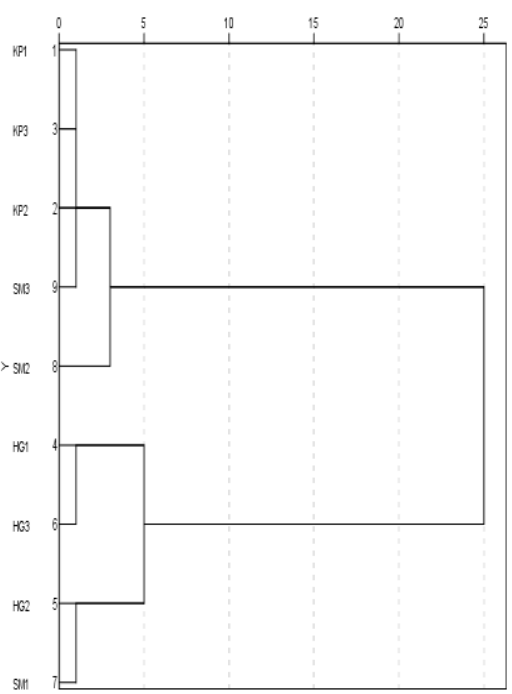

C:N Ratio

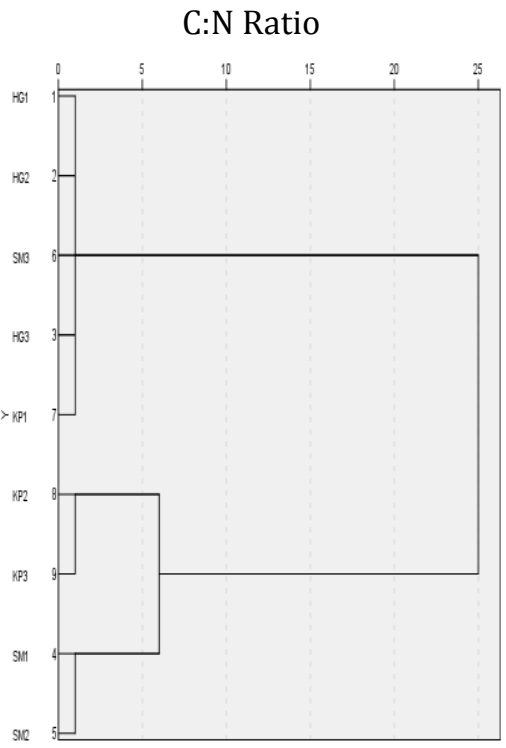

Phosphorus

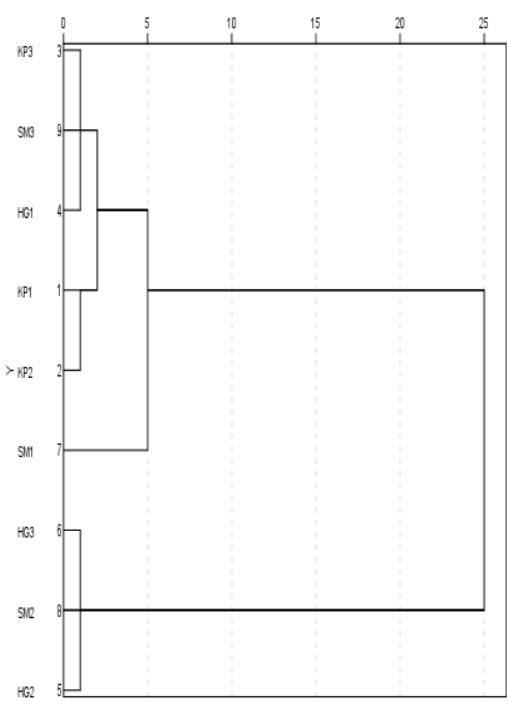

Organic Material

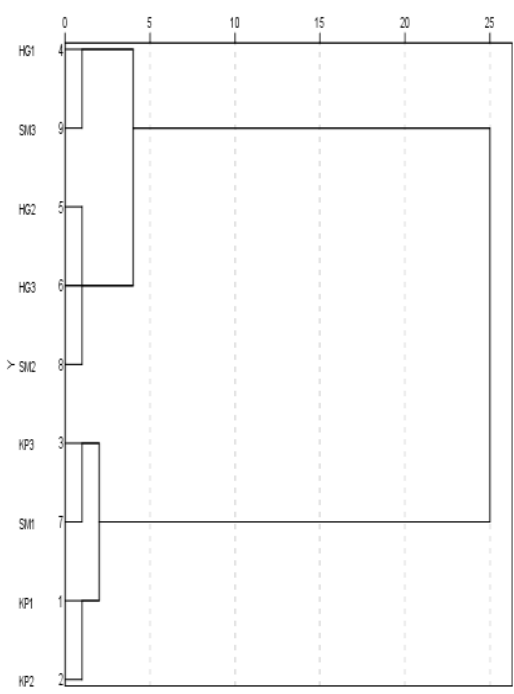

Potassium

Figure 2. Dendrogram for soil chemical properties of Banj-oak, Chir-pine and Sal Forest (Abbreviations: Soil depths in cm: 1, 2, $3(0-10 \mathrm{~cm}, 11-20 \mathrm{~cm}, 21-30 \mathrm{~cm})$, KP: Banj-oak forest, HG: Chir-pine forest, SM: Sal forest) 

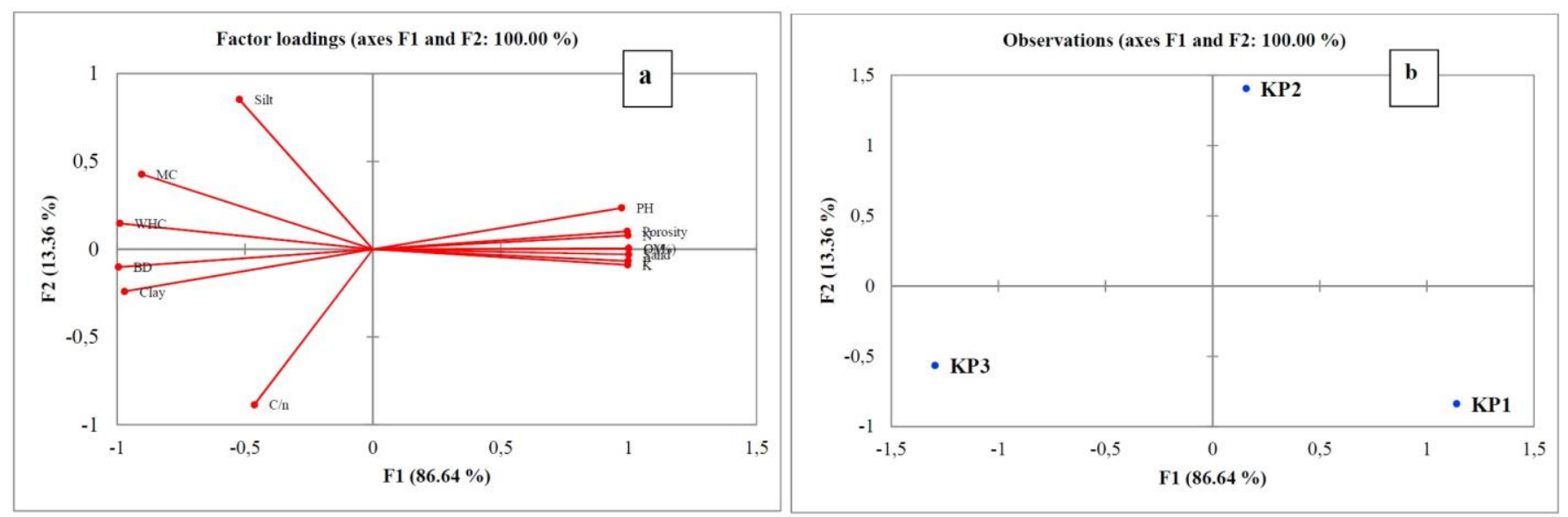

Figure 4. Factor analysis and observation plot for Physico-chemical properties of Banj-oak forest(a,b)
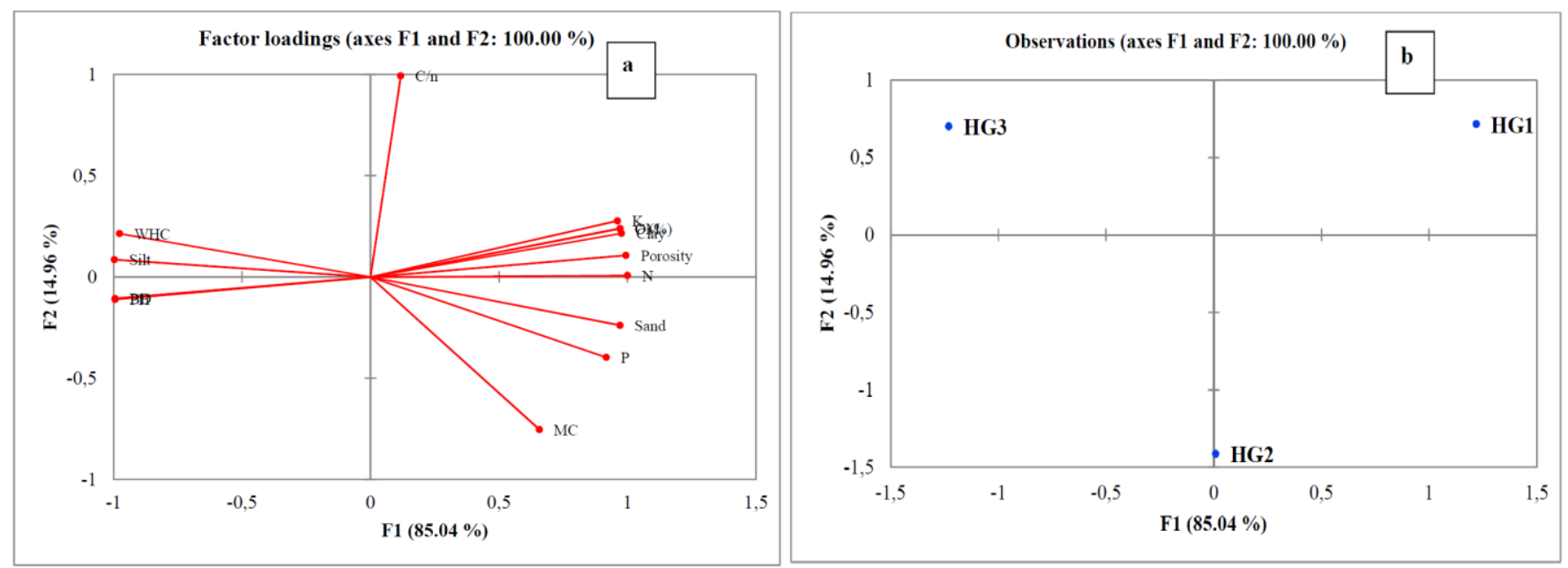

Figure 5. Factor analysis and observation plot for Physico-chemical properties of Chir-pine forest (a,b)
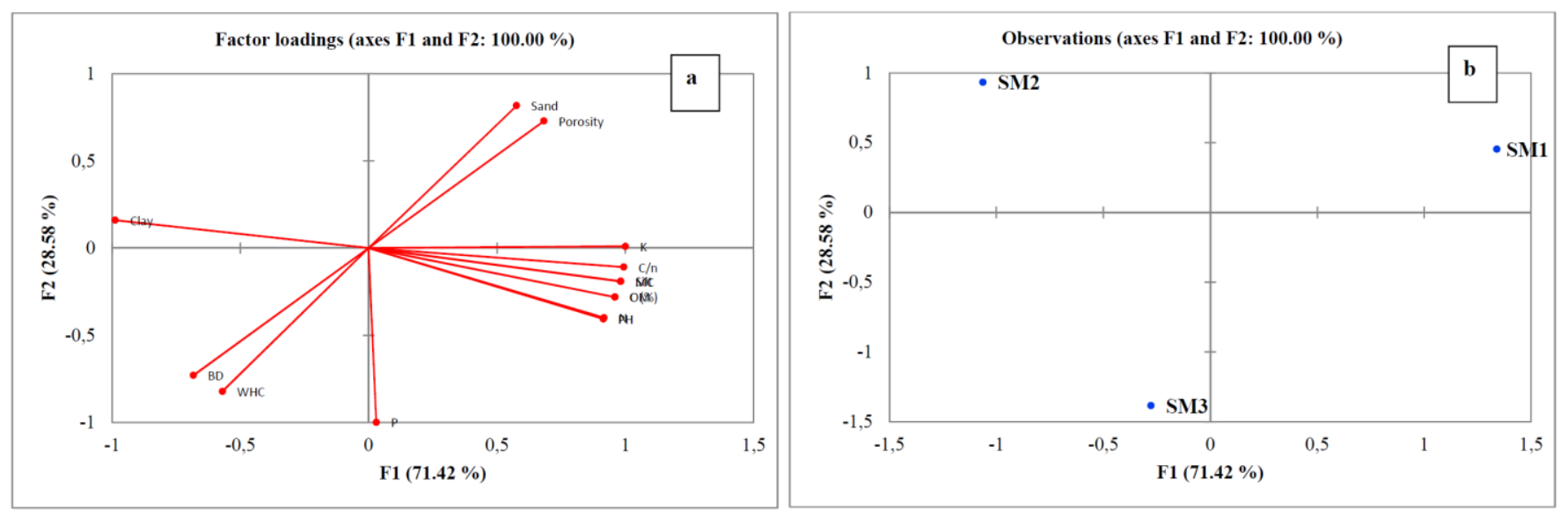

Figure 6. Factor analysis and observation plot for Physico-chemical properties of Sal forest (a,b)

\section{Conclusion}

Observation shows that soil nutrients in banj-oak forest are rich at $(21-30 \mathrm{~cm})$ depth while in sal and chirpine forest soil nutrients are rich in upper most depth $(0-10 \mathrm{~cm})$. Among all three forest type banj-oak forest shows rich values of soil physical properties (moisture content, bulk density, water holding capacity), while sal forest shows richness of chemical properties (organic carbon, organic matter, nitrogen content). Correlation analysis of soil physic-chemical properties showed that silt, c:n ratio, potassium, carbon and nitrogen have maximum positive correlation with physico-chemical properties while clay showing maximum negative correlation with physico-chemical properties. The cluster analysis concluded that soil physico-chemical properties of three depths $(0-10 \mathrm{~cm}, 11-20 \mathrm{~cm}, 21-30 \mathrm{~cm})$ from three forests differentiated from each other. The factor analysis concluded that sand, porosity, carbon and nitrogen in all the forest have 
maximum positive correlation in compared to other physico-chemical properties. The observation analysis concluded that upper depths $(0-10 \mathrm{~cm})$ of all the forest have close correlation in compared to other depths. It is a very important soil property influencing soil structure, stability, nutrient availability, soil pH and soil's reaction toward fertilizers and other amendments (Hazelton and Murphy, 2007). On the basis of above observation we concluded that mixed forest like banj-oak should promote for better soil health, which is good for germination of seeds because of high moisture content and water holding capacity.

\section{Acknowledgement}

The authors are thankful to Director, Regional Ayurvedic Research Institute (RARI), CCRAS, Thapla, Ranikhet, and Head, Department of Botany, Kumaun Universtiy, Nainital for providing infrastructure, facilities and encouragement. We are also thankful to Soil testing laboratory, Bhowali and IERP, GBPNIHESD, Kosi Katarmal, Almora.

\section{References}

Bharti, M., Tewari, L., Tewari, A., Joshi, N., 2016. Impact of Alien invasive species on soil physiochemical characteristics in tropical Sal forest, Uttarakhand, India. Journal of Chemical Engineering and Chemistry Research 3(11): 10571061.

Bhatnagar, H.P., 1965. Soils from different quality sal (Shorea robusta Gaertn.) forests of Uttar Pradesh. Tropical Ecology 6: 56-62.

Bhatt, V.P., Purohit, V.K., 2009. Floristic structure and phytodiversity along an elevational gradient in PeepalkotiJoshimath area of Garhwal Himalaya, India. Nature and Science 7(9): 63-74.

Bhatt, D.D., 1981. Nepal Himalaya and change. In: Himalaya: Aspects of change. Laal JS (ed), Oxford University Press. New Delhi, India. pp. 253-777.

Black, C.A., 1965. Methods of soil analysis. Part 1 Physical and mineralogical properties, American Society of Agronomy, No:9. Madison, WI, USA.

Champan, J.L., Reiss, M.J., 1992. Ecology principles and application. Cambridge University Press. Cambridge, UK. 294p.

Champion, H.G., Seth, S.K., 1968. A revised survey of the forest types of India. Manager of Publications, New Delhi. India. 404p.

Deka J, Tripathi, O.P., Khan, M.L., 2012. High dominance of Shorea robusta Gaertn. f. in alluvial plain kamrup sal forest of Assam, N. E. India. International Journal of Ecosystem 2(4): 67-73.

Gairola, S., Sharma, C.M., Ghildiyal, S.K., Suyal, S., 2012. Chemical properties of soils in relation to forest composition in moist temperate valley slopes of Garhwal Himalaya, India. The Environmentalist 32(4): 512-523.

Gupta, R.P., Dhakshinamoorthy, C., 1980. Procedures for physical analysis of soils and collection of agrometerological data. Indian Agricultural Research Institute, Division of Agricultural Physics, New Delhi, India.

Hazelton, P.A., Murphy, B.W., 2007. Interpreting soil test results: What do all the numbers mean? CSIRO Publishing, Melbourne $152 \mathrm{p}$.

Ilorker, V.M, Totey, N.G., 2001. Floristic diversity and soil studies in Navegaon National Park (Maharashtra). Indian Journal of Forestry 24(4): 442-447.

Jackson, M.L., 1958. Soil Chemical Analysis, Prentice Hall Inc. Englewood Cliffs, New Jersey, USA. 498p.

Jina, B.S., Bohra, C.S., Lodhiyal, L.S., Sah, P., 2011. Soil characteristics in oak and pine forests of Indian Central Himalaya. E-International Scientific Research Journal 3(1): 19-22.

Johnston, A.E., 1986. Soil organic matter, effects on soil and crops. Soil Use and Management 2(3): 97-105.

Joshi, G., Negi, G.C.S., 2015. Physico-chemical properties along soil profile of two dominant forest types in Western Himalaya. Current Science 109 (4):798-803.

Joshi, P.C., Pandey, P., Kaushal, B.R., 2013. Analysis of some Physico-chemical parameters of soil from a protected forest in Uttarakhand. Nature and Science 11(1):136-140.

Khera, N., Kumar, A., Ram, J., Tewari, A., 2001. Plant biodiversity assessment in relation to disturbances in mid elevational forest of Central Himalaya, India. Tropical Ecology 42(1): 83-95.

Kjeldahl, J., 1883. Neue Methode zur Bestimmung des Stickstoffs in organischen Körpern. Zeitschrift für analytische Chemie 22(1): 366-382.

Kotiyal, P.B., Sinha, S., 2015. Assessment of nutrient status and soil health under various landuses of Tehri District of Uttarakhand. eJournal of Applied Forest Ecology 3(2): 43-47.

Kumar, M., Sharma, C.M, Rajwar, G.S., 2004. Physico-chemical properties of forest soil along altitudinal gradient in Garhwal Himalaya. Journal of Hill Research 17(2):60-64.

Kumar, M., Singh, H., Bhat, J.A., Rajwar, G.S., 2013. Altitudinal variation in species composition and soil properties of Banj Oak and Chir Pine dominated forests. Journal of Forest and Environmental Science 29 (1): 29-37.

Mehta, J.P., Shreshthamani, Bhatt, V.P., 2014. Analysis of the physico-chemical properties of the soil and climatic attribute on vegetation in Central Himalaya. Nature and Science 12 (11): 46-54.

Olsen, S.R., Sommers, L.E.,1982. Phosphorus. In: Methods of soil analysis. Part 2 Chemical and microbiological properties. 2nd edition. Page, A.L. (Ed.). American Society of Agronomy, No. 9, Madison, WI, USA. pp. 403-430. 
Pastor, J., Aber, J.D., McClangherty C.A., Melillo, J.M.,1984. Aboveground production and N and P cycling along a nitrogen mineralization gradient on Blackhawk Island, Wisconsin. Ecology 65(1): 256-268.

Paudel, S., Sah, J.P., 2003. Physiochemical characteristics of soil in tropical sal (Shorea robusta Gaertn.) forests in eastern Nepal. Himalayan Journal of Science 1(2): 107-110.

Piper, C.S., 1950. Soil and plant analysis. Interscience Publishers Inc., New York, USA.

Piper, C.S., 1966. Soil and plant analysis (Asian edition). Hans Publishers., Bombay, India. pp. 223-237.

Sapkota, I.P., Tigabu, M., Odén, P.C., 2009. Spatial distribution, advanced regeneration and stand structure of Nepalese Sal (Shorea robusta) forests subject to disturbances of different intensities. Forest Ecology and Management 257(9): 1966-1975.

Satya, Upreti, D.K., Nayaka, S., 2005. Shorea robusta- an excellent host tree for lichen growth in India. Current Science 89 (4): 594-595.

Semwal, D.D., Uniyal, P.L., Bahuguan, Y.M., Bhatt, A.B., 2009. Soil nutrient storage under different forest types in a part of Central Himalayas, India. Ann. For 17(1): 43-52.

Sharma, C.M., Gairola, S., Ghildiyal, S.K., Suyal, S., 2010. Physical properties of soils in relation to forest composition in moist temperate valley slopes of the Central Western Himalaya. Journal of Forest Science 26(2): 117-129.

Sheikh, A. M., Kumar, M., 2010. Nutrient status and economic analysis of soils in oak and pine forests in Garhwal Himalaya. Journal of American Science 6(2): 117-122.

Singh, H., Kumar, M., Sheikh, A.M., 2009. Distribution pattern of Oak and Pine along altitudinal gradients in Garhwal Himalaya. Nature and Science 7(11): 81-85.

Singh, J.S., Singh, S.P., 1987. Forest vegetation of the Himalaya. The Botanical Review 53(1): 80-192.

Tewari, G., Khati, D., Rana, L., Yadav, P. Pande, C., Bhatt, S., Kumar, V., Joshi, N., Joshi, P.K., 2016. Assessment of physicochemical properties of soils from different land use systems in Uttarakhand, India. Journal of Chemical Engineering and Chemistry Research 3(11): 1114-1118.

Upreti, B.M., Tewari, L., Tewari, A., Joshi, N., 2016. Physiochemical characterization of soil collected from sacred and non sacred forests of Uttarakhand: A comparative study. Journal of Chemical Engineering and Chemistry Research 3(11): 989-992.

Walkley, A., Black, I.A., 1934. An examination of the Degtjareff method for determining soil organic matter, and a proposed modification of the chronic acid titration method. Soil Science 37(1): 29-38. 